\title{
PROPERTIES OF PARTICLEBOARD PANELS MADE OF SUGARCANE PARTICLES WITH AND WITHOUT HEAT TREATMENT
}

Emerson Gomes Milagres $^{2 *} \odot$, Raiana Augusta Grandal Savino Barbosa ${ }^{2}$, Karine Fernandes Caiafa $^{3} \odot$,

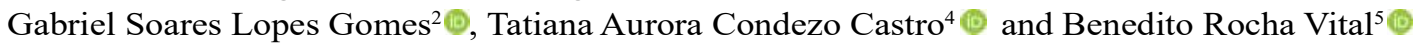

\footnotetext{
${ }^{1}$ Received on 13.03.2019 accepted for publication on 15.08.2019.

${ }^{2}$ Universidade Federal de Viçosa, Programa de Pós-Graduação em Ciência Florestal, Viçosa, MG - Brasil. E-mail: <e.milagres@yahoo. com.br>, <rai_grandal@yahoo.com.br> and < gabriel.flo@hotmail.com>.

${ }^{3}$ Universidade Federal de Viçosa, Departamento de Engenharia Florestal, Viçosa, MG - Brasil. E-mail: <karinecaiafa@yahoo.com.br>.

${ }^{4}$ Universidade Federal de Viçosa, Programa de Pós-Graduação em Tecnologia de Celulose de Papel, Viçosa, MG - Brasil. E-mail: $<$ tatianacondezo@gmail.com>.

${ }^{5}$ Universidade Federal de Viçosa, Departamento de Engenharia Florestal, Viçosa, MG - Brasil. E-mail: <benedito.vital@gmail.com>.

*Corresponding author.
}

\begin{abstract}
The objective of this work was to determine the properties of particleboard panels made of "in natura" sugarcane bagasse particles, heated at $250^{\circ} \mathrm{C}$ for 5 minutes. Various particle proportions were utilized to produce the panels and their properties were compared with that of a panel made of Pinus sp. The panels were produced with $8 \%$ tannin formaldehyde adhesive, and $0.5 \%$ paraffin emulsion, being pressed at $32 \mathrm{kgf}$. $\mathrm{cm}^{-2}$ for 10 minutes at $180^{\circ} \mathrm{C}$. It was determined the basic density of the "in natura" and heat-treated particles, their chemical composition, as well as the compression ratio necessary to obtain panels with density equal to $0.75 \mathrm{~g} . \mathrm{cm}^{-3}$. The basic density of the panels, hygroscopic equilibrium humidity, thickness swelling, linear expansion, water vapor adsorption, modulus of elasticity and rupture, perpendicular traction, screw pullout, and Janka hardness were determined. The basic densities of Pinus particles and sugarcane bagasse without and with heat treatment were $0.46,0.27$ and $0.30{\mathrm{~g} . \mathrm{cm}^{-3}}^{-3}$ respectively. The average specific mass of the panels was 0.74 g. $\mathrm{cm}^{-3}$ with no significant difference between them. Generally, panels made of sugarcane particles were less hygroscopic and dimensionally more stable than panels made of Pinus particles. However, the perpendicular tensile strength, screw pullout and Janka hardness of these panels were higher than for the Pinus panels. The heat treatment of sugarcane bagasse particles resulted in better mechanical properties of perpendicular traction and Janka hardness. In general, the panels are within the limits set by ANSI A208.1. It is therefore possible to replace panels made of Pinus particles for the ones made of sugarcane bagasse, provided that at least $25 \%$ of the particles are heat treated for 5 minutes at $250^{\circ} \mathrm{C}$.
\end{abstract}

Keywords: Physical property; Mechanical property; Agricultural residue.

\section{PROPRIEDADES DE PAINÉIS AGLOMERADOS CONFECCIONADOS COM PARTÍCULAS DE BAGAÇO DE CANA COM E SEM TRATAMENTO TÉRMICO}

RESUMO - O objetivo deste trabalho foi determinar as propriedades de painéis aglomerados confeccionados com partículas de bagaço de cana-de-açúcar in natura e aquecidas a $250{ }^{\circ} \mathrm{C}$ durante 5 minutos. Foram empregadas várias proporções de partículas na confecção dos painéis e as suas propriedades foram comparadas com as propriedades de um painel fabricado com partículas de Pinus sp. Os painéis foram produzidos com $8 \%$ de adesivo à base de tanino formaldeído, 0,5\% de emulsão parafinica e prensados a $32 \mathrm{~kg}$.cm-2, por 10 minutos, à temperatura de $180^{\circ} \mathrm{C}$. Determinou-se a densidade básica das partículas in natura e termotratadas, sua composição química bem como a taxa de compressão necessária para obter painéis com densidade igual a 0,75 g.cm-3. Determinou-se a densidade básica dos painéis, umidade de equilíbrio higroscópico, inchamento em espessura, expansão linear, adsorção de vapor de água, módulo de elasticidade e de ruptura, tração perpendicular, arrancamento de parafuso e dureza Janka. As densidades básicas das partículas de Pinus e do bagaço de cana sem e com tratamento térmico foram de 0,46, 0,27 e 0,30 g.cm-3, respectivamente. A massa especifica média dos painéis foi igual a 0,74 g.cm-3 sem diferença significativa entre eles. Geralmente, os 


\begin{abstract}
painéis fabricados com partículas de cana-de-açúcar foram menos higroscópicos e dimensionalmente mais estáveis do que os painéis fabricados com partículas de Pinus. Contudo, a resistência à tração perpendicular, o arrancamento de parafuso e a dureza de Janka destes painéis foram maiores. O tratamento térmico das partículas de bagaço de cana resultou em melhores propriedades mecânicas de tração perpendicular e dureza de Janka. De modo geral, os painéis estão dentro dos limites estabelecidos pela norma ANSI A208.1. Portanto, é possivel substituir painéis confeccionados com partículas de Pinus por bagaço de cana de açúcar, desde de que, pelo menos $25 \%$ das partículas sejam tratadas termicamente durante 5 minutos à temperatura de $250^{\circ} \mathrm{C}$.
\end{abstract}

Palavras-Chave: Propriedade física; Propriedade mecânica; Resíduo agrícola.

\section{INTRODUCTION}

Agroindustrial companies generate lignocellulosic waste, whose use can incorporate values into the commercial activity and reduce the emission of pollutant gases in Brazil. In the 2017/2018 period, about 635.6 thousand tons of sugarcane were harvested (Conab, 2017). Each ton of sugarcane generates about $280 \mathrm{~kg}$ of bagasse (Silva et al. 2007). About $70 \%$ of this bagasse is burned for power generation that is consumed in the industry itself, and the remaining $30 \%$ is sold for composting (Battistelle et al., 2016). However, other industries can use sugarcane bagasse as raw material, adding value to this product.

The manufacture of particleboard panels is one of those alternatives. In addition to adding value to the residue, the production of particleboard of sugarcane bagasse can reduce the price of panels, making them more economically competitive and reducing the demand for wood from forests.

Several researchers have already demonstrated the technical feasibility of using sugarcane bagasse particles as a raw material for the manufacture of panels. However, regardless of the raw material, particleboards have low moisture resistance and are dimensionally unstable, thus limiting their possible uses (Melo et al., 2009; Mendes et al., 2010; Soares et al., 2017).

Thus, in order to solve this problem, some propositions are described in the literature, such as the heat treatment of the particles. This may be a promising alternative for improving panel quality, but the results founded are quite contrasting (Araújo et al., 2012; Vital et al., 2014).

Vital et al. (2014) attribute part of this to the particularities present in the wood of each species, in addition to the variations in the conditions under which the heat treatment is performed, such as atmosphere characteristics, which is oxidizing or inert, dry or humid.
In this context, the objective of this work was to determine the physical and mechanical properties of particleboards produced from sugarcane bagasse particles with and without heat treatment in different proportions, and to compare them with the panels produced with Pinus particles.

\section{MATERIALS AND METHODS}

The particles of Pinus sp. were produced from 30 -year-old logs obtained from the plantations of the Federal University of Viçosa. The sugarcane bagasse was donated by the company Jatiboca Sugar and Alcohol, located in the municipality of Urucânia, state of Minas Gerais.

Using a band saw, the Pinus logs were split into $23 \mathrm{~mm}$ thick planks, which were later cut into 90 $\mathrm{mm}$ blocks using a circular saw. These blocks were submerged in water until complete saturation and then processed in a disc-type chipper. After this stage, the particles were processed in a $3 \mathrm{~mm}$ mesh hammer mill and qualified in a $3 \mathrm{~mm}$ hand sieve. The particles were placed in an oven at $45^{\circ} \mathrm{C}$ until they reached $3 \%$ humidity, and then they were bagged.

The sugarcane bagasse particles were dried at room temperature, processed in a $3 \mathrm{~mm}$ mesh hammer mill, and, subsequently, manually sieved in the $3 \mathrm{~mm}$ hand sieve. Half of these material was placed in an oven at $45{ }^{\circ} \mathrm{C}$ until $3 \%$ humidity, while the other part was heat treated at $250^{\circ} \mathrm{C}$ for five minutes in a reactor endless screw type, developed at the Wood Energy and Panels Laboratory as described by Magalhães et al. (2018). After this stage, the heat treated particles were again manually sieved in a $3 \mathrm{~mm}$ sieve, oven dried at $45{ }^{\circ} \mathrm{C}$ until $3 \%$ humidity.

After preparation of the particles, a sample was used for the chemical composition analysis. Initially, the samples were turned into sawdust using a laboratory mill Willey-type according to TAPPI

Revista Árvore 2019;43(5):e430502 
257 om-52 (Tappi, 1994). The fraction that passed through the $40 \mathrm{~mm}$ mesh was collected and retained in the $60 \mathrm{~mm}$ mesh (Astm, 1982). The determination of the absolutely dry content of the samples was performed according to TAPPI 264 om-88 (Tappi, 1996).

The extractives contents in the samples were determined in duplicate, according to TAPPI 204 om88 (Tappi, 1996), using the total extractives method, with the substitution of ethanol/benzene by ethanol/ toluene.

Insoluble lignin contents were determined in duplicate by the Klason method, modified according to the procedure proposed by Gomide and Demuner (1986), derived from the Tappi T222 om-88 standard (Tappi, 2000). Soluble lignin was determined by spectrometry (Goldschimid, 1971) by diluting the filtrate from the procedure to obtain insoluble lignin. The total lignin content was obtained by the sum of both soluble and insoluble lignin values and the holocellulose content was obtained by the sum of the total extractives and lignin contents, subtracted from 100.

The basic density of Pinus particles and sugarcane bagasse without and with heat treatment was determined according to the methodology proposed by Vital (1984). When the panels contained in their composition two types of particles of different specific masses, the proportion of particles used in the treatment multiplying by their basic density was taken into account.

The adhesive used in the manufacture of the panels was the tannin extracted from the bark of Acacia decurrens, specified as PHENOTAN AP, donated in powder form by the company TANAC S / A, located in the city of Montenegro, state of Rio Grande do Sul. The characterization of the adhesive was made 24 hours after its hydration, using a proportion of 55\% water to $45 \%$ tannin powder adhesive.

The solids content of the adhesives was calculated according to Astm D 1490-01 (2013). The pH was determined by direct measurement in a $\mathrm{pH}$ meter Digimed DM-2P, at $25^{\circ} \mathrm{C}$, in samples of approximately $200 \mathrm{~mL}$ following E70 - 07 (Astm, 2015). The viscosity of the adhesives was determined according to ASTM D 1084 - 97 (Astm, 1998) (method B). For this, a Brookfield viscometer with Spindler rod number 3 and a speed of $12 \mathrm{rpm}$ was used. The gelatinization time was determined at $180{ }^{\circ} \mathrm{C}$ according to D 2471-99 (Astm, 1999).

All tests were done in triplicate and the adhesive had a solids content of $41.92 \%, \mathrm{pH}$ of 7.69 , viscosity of $1016 \mathrm{cP}$, and gelatinization time of 52 seconds.

To prepare the adhesives were added $10 \%$ of formalin, based on the solid content of the adhesive before applying the resin to the particles.

The panels were manufactured with thermalrectified "in natura" particles in the proportions of $0,25,50,75$ and 100\% respectively, besides those containing only Pinus particles. For this, the particles were mixed with tannic adhesive in the proportion of $8 \%$ of the solids content of the adhesive and $0.5 \%$ of paraffin in relation to the dry mass of particles. The mats was manually formed in a box with dimensions of $40.0 \times 40.0 \mathrm{~cm}$ with a mass of particles required to obtain panels with a thickness of $1.0 \mathrm{~cm}$ and a density equal to $0.75 \mathrm{~g} . \mathrm{cm}-3$. The particles were pressed at 32 Kgf.cm-2 at $180^{\circ} \mathrm{C}$ for 10 minutes. Subsequently, the panels were conditioned at a temperature of $20 \pm$ $3{ }^{\circ} \mathrm{C}$ and relative humidity of $60 \pm 5 \%$ until reaching equilibrium humidity.

The panels were then squared by removing $2.0 \mathrm{~cm}$ on each side and their surfaces were sanded. The specimens were then removed to determine their properties.

All properties (basic density, hygroscopic equilibrium humidity, thickness swelling, linear expansion, water vapor adsorption, elastic modulus (MOE) and rupture modulus (MOR), perpendicular traction, screw pullout, and Janka hardness) were determined according to the procedure described in standard D 1037-93 (Astm, 2002). For the perpendicular screw pullout test, the specimens were adapted to $7.6 \times 10.2 \times 2.0 \mathrm{~cm}$ in width, length, and thickness, respectively. The compaction rate was obtained by dividing the panel density by the particle density considering the proportion used to manufacture the panels. The water vapor adsorption test was chosen over water absorption due to the panel's ultimate utility.

The results were compared to the minimum values required by Ansi A208.1 (1993) for medium density panels.

The experiment was installed following a completely randomized design, with six panels types containing three replications, generating a total of 18 panels.

Revista Árvore 2019;43(5):e430502 
The results were interpreted with the help of analysis of variance (ANOVA). When significant differences were observed, the treatments were compared with the Tukey test at 5\% significance, using the Statistica software.

\section{RESULTS}

The average density of the panels made of particle mixture as well as the compaction rate can be observed in table 1 . The average value of the panel's density was 0.74 g.cm-3 with no significant difference as a function of the treatments. As per ANSI / A-208.1 (1993) these panels are classified as medium density. As expected, the compaction rate was inversely proportional to the basic particle density.

Table 2 shows the average chemical composition of "in natura" particles of sugarcane bagasse, heattreated, and pine particles.

The average values of the physical properties of the manufactured panels are shown in Figure 1.

The hygroscopic equilibrium humidity of panels made of Pinus particles was significantly higher than that of other panels. It is also observed that the addition of thermal-rectified particles of sugarcane bagasse reduced the hygroscopicity of the panels (Figure 1A).

The thickness swelling was lower in panels containing larger proportions of heat-treated particles (above 75\%) in their composition (Figure 1B).
The heat treatment of the particles significantly reduced the linear expansion of the panels (Figure 1C).

Panels made of Pinus particles, although more stable, adsorbed less water vapor than panels made of "in natura" and heat treated particles of sugarcane bagasse (Figure 1D).

The average values of the mechanical properties of the manufactured panels can be observed in Figure 2.

The addition of heat treated particles to the sugarcane bagasse panels improved the perpendicular tensile strength, but the Pinus panels were more resistant (Figure 2A).

The average values of screw pullout resistance perpendicular to the surface of the panels produced with pine particles were higher than the others (Figure 2B).

The addition of treated sugarcane bagasse particles to the panels increased their Janka hardness, resembling the hardness of the Pinus panels (Figure 2C).

The panels produced with different percentages of heat treated and untreated cane particles and panels produced with Pinus particles showed no significant difference for MOE (Figure 2D) and MOR (Figure 2E).

\section{DISCUSSION}

The use of low density wood particles allows the production of panels with better mechanical properties

Table 1 - Mean values of the basic density of the panels, basic density of the particles used for panel production and the compression ratio. Tabela 1 - Valores médios de densidade básica dos painéis, densidade básica das partículas utilizadas para a produção do painel e a taxa

\begin{tabular}{|c|c|c|c|}
\hline \multirow[t]{2}{*}{$\overline{\text { Panel }}$} & DP & DPPFP & $\mathrm{TC}$ \\
\hline & g. $\mathrm{cm}^{-3}$ & g.cm ${ }^{-3}$ & \\
\hline Pinus & $0,74(0,05) \mathrm{a}$ & 0,460 & $1,61(0,10) \mathrm{a}$ \\
\hline $100 \% \mathrm{BG}$ & $0,74(0,03) \mathrm{a}$ & 0,270 & $2,74(0,11) \mathrm{a}$ \\
\hline $75 \%$ BG $25 \%$ BGT & $0,74(0,02) \mathrm{a}$ & 0,278 & $2,67(0,07) \mathrm{ab}$ \\
\hline $50 \%$ BG $50 \%$ BGT & $0,74(0,01) \mathrm{a}$ & 0,285 & $2,60(0,03) \mathrm{ab}$ \\
\hline $25 \%$ BG $75 \%$ BGT & $0,74(0,03) \mathrm{a}$ & 0,295 & $2,53(0,09) b$ \\
\hline $100 \% \mathrm{BGT}$ & $0,75(0,02) \mathrm{a}$ & 0,300 & $2,50(0,06) b$ \\
\hline
\end{tabular}

Where: DP = Panel Density, DPPFP = Particle Density considering the proportion used to manufacture the panels, TC = Compaction Rate. Means with the same letter do not differ statistically by the Tukey test at $5 \%$ probability. Overridden values indicate standard deviation

Table 2 - Average chemical composition of "in natura" sugarcane bagasse particles, heat treated and Pinus particles (\%).

Tabela 2 - Composição química média de partículas do bagaço de cana in natura, termorretificadas e partículas de Pinus (\%).

\begin{tabular}{lccc}
\hline Material & Holocellulose & Lignin & Extractives \\
\cline { 2 - 4 } & $\%$ & $\%$ & \\
\hline Bagasse & 72,76 & 22,18 & \\
Termal-rectified bagasse & 69,60 & 23,84 & \\
Pinus & 55,66 & 30,37 & 6,56 \\
\hline
\end{tabular}

Revista Árvore 2019;43(5):e430502 

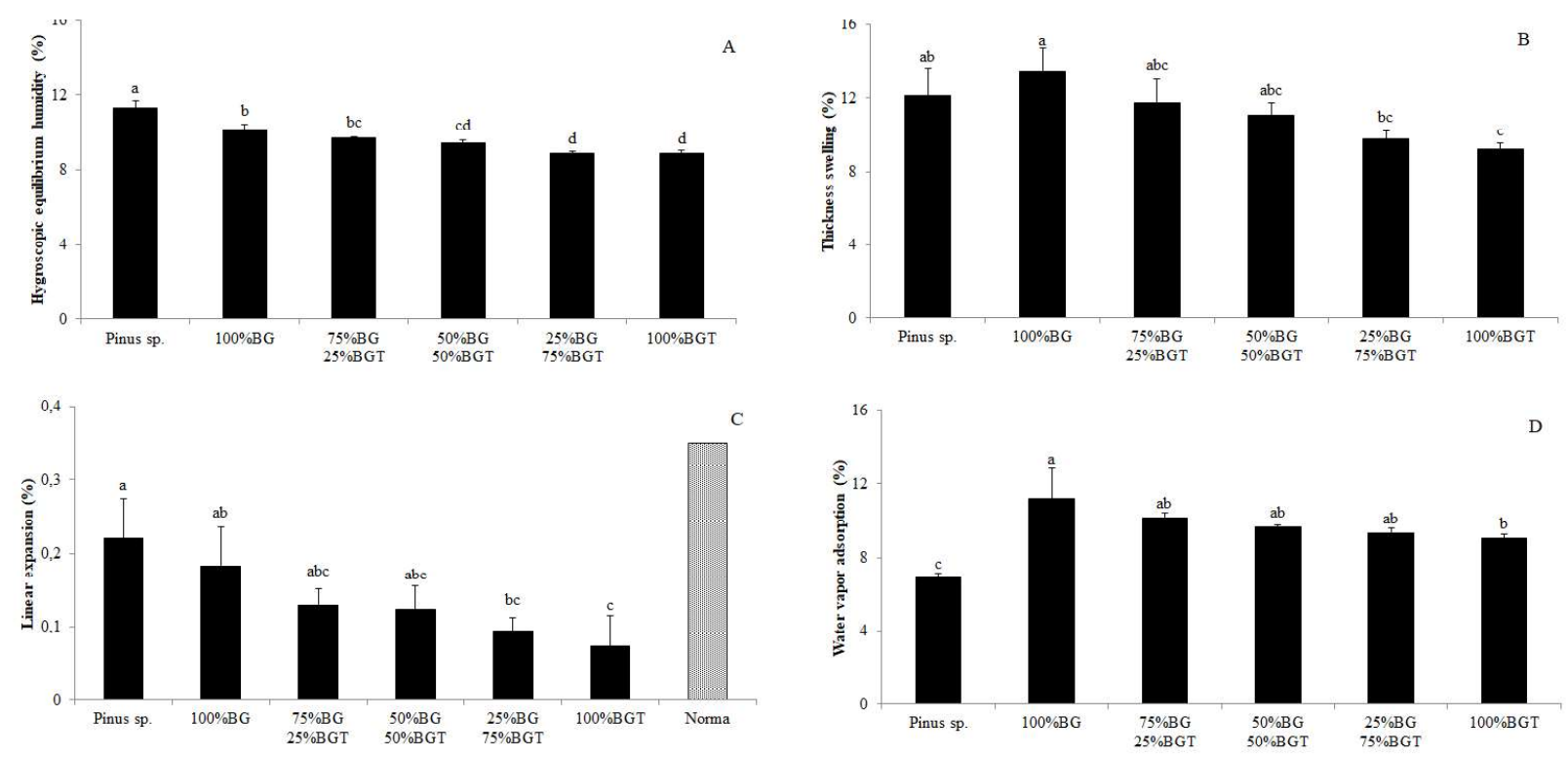

Figure 1 - Physical properties of the panels according to their composition. Hygroscopic equilibrium humidity (A), Thickness swelling (B), Linear expansion (C) and Water vapor adsorption (D). Means with the same letter do not differ significantly by the Tukey test at $5 \%$ probability. Error bars indicate the standard deviation. (Being BG = "in natura" sugarcane bagasse; BGT = thermally treated sugarcane bagasse).

Figura 1 - Propriedades físicas dos painéis em função da sua composição. Umidade de equilibrio higroscópico (A), Inchamento em espessura (B), Expansão linear (C) e Adsorção de vapor D'água (D). Médias com mesma letra não diferem significativamente pelo teste Tukey a 5\% de probabilidade. Barras de erro indicam o desvio padrão (sendo BG = bagaço de cana "in natura"; BGT = bagaço de cana termicamente tratado).

than the ones produced with higher density particles. Panels with a compaction ratio between 1.3 and 1.6 are ideal, because in this range there is a good contact between the particles, thus improving the adhesion (Maloney, 1993).

However, to obtain panels with desired density it was necessary to employ higher compaction rates (Table 1). This may have damaged the particles, reducing their strength and causing a reduction in the mechanical properties of the panels (Figures 2A, 2B and 2C).

It is also emphasized that the heat treatment of sugarcane bagasse particles increased their density (Table 1). One of the possible explanations for this fact is that the heat treatment promotes a larger volumetric contraction than the reduction of the mass of these particles (Santos et al., 2014; Vital and Trugilho, 1997). This is due to the reduction of available $\mathrm{OH}$ groups for the adsorption of water molecules, thus promoting a closer approximation of cellulose molecules after heat treatment.
As can be seen in table 1 , even in panels with $100 \%$ heat treated sugarcane bagasse particles, the compaction rate was still high (2.50).

Regarding the chemical composition of sugarcane bagasse, results similar to the ones of this study were found by Benjamin et al. (2014) and Rocha et al. (2015), which, respectively, mention averages of $63.88 \%$ and $69.79 \%$ for holocellulose, $18.17 \%$ and $21.56 \%$ for lignin and $6.86 \%$ and $5.63 \%$ for extractives. In contrast, Protásio et al. (2015) report higher levels of extractives for sugarcane bagasse in relation to Pinus wood, citing $12.46 \%$ and $10.84 \%$, respectively. Del Rio et al. (2015) point out that the high levels of extractives that may be found in sugarcane bagasse may be due to the solvent used for their removal, usually $95 \%$ ethanol, which also has the ability to extract low molecular weight carbohydrates, such as salts, polyphenols and other water soluble components.

It can be seen from Figure $1 \mathrm{~A}$ that the hygroscopic equilibrium humidity of all panels made of sugarcane

Revista Árvore 2019;43(5):e430502

\section{Silf}



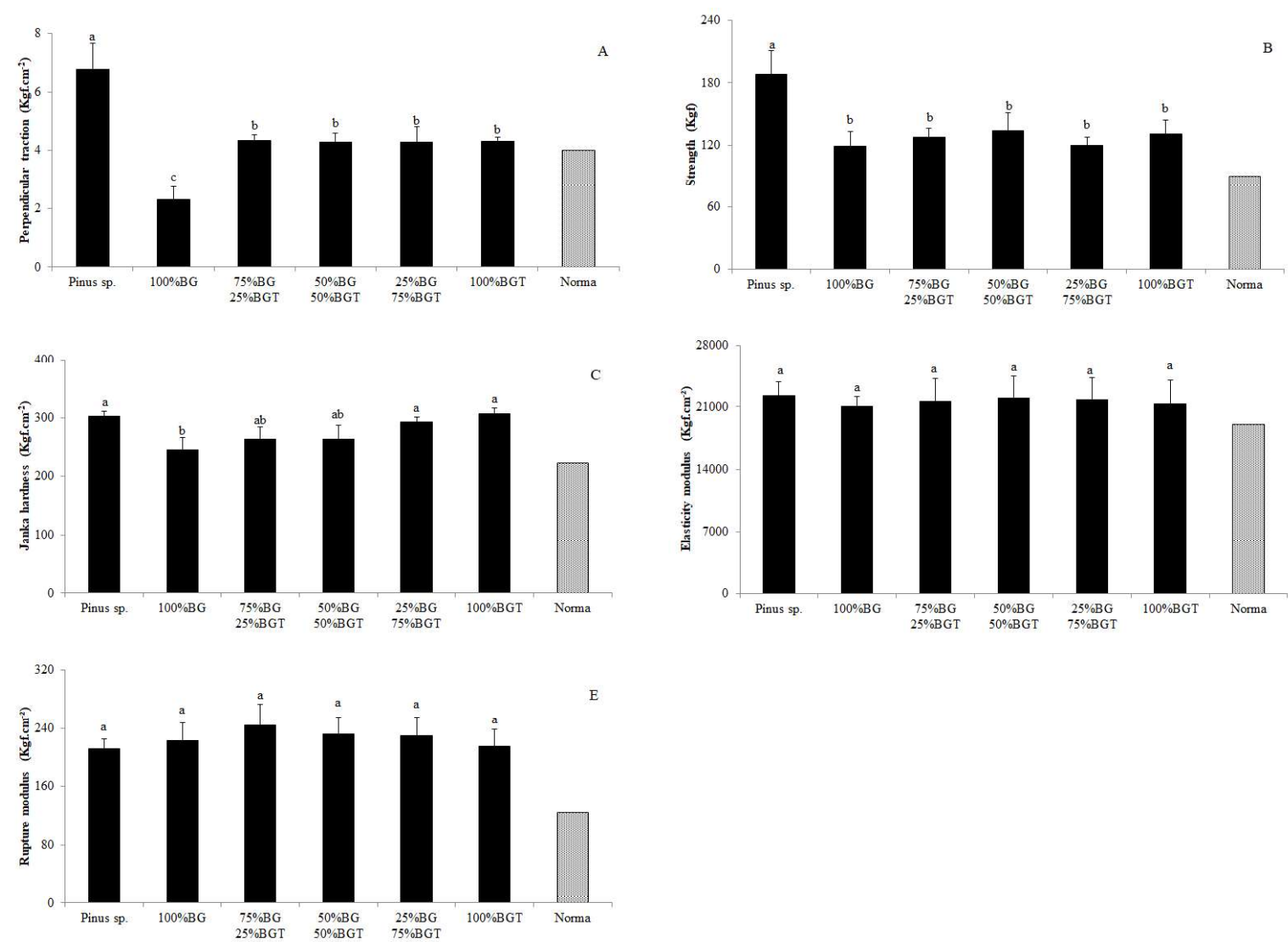

Figure 2 - Mechanical properties of the panels according to their composition and minimum value established by ANSI / A 208.1 (1993). Perpendicular traction (A), Strength (B), Janka hardness (C), Elasticity modulus (D) and Rupture modulus (E). Means with the same letter do not differ significantly by the Tukey test at 5\% probability. Error bars indicate the standard deviation. (Being BG $=$ "in natura" sugarcane bagasse; BGT = thermally treated sugarcane bagasse).

Figura 2 - Propriedades mecânicas dos painéis em função da sua composição e valor mínimo estabelecido pela norma ANSI/A 208.1 (1993). Tração perpendicular (A), Resistência (B), Dureza Janka (C). Módulo de Elasticidade (D) e Módulo de Ruptura (E). Médias com mesma letra não diferem significativamente pelo teste Tukey a 5\% de probabilidade. Barras de erro indicam o desvio padrão (sendo $B G=$ bagaço de cana "in natura"; $B G T=$ bagaço de cana termicamente tratado).

bagasse particles was significantly lower than that made of Pinus particles. The addition of thermal-rectified bagasse particles further reduced the hygroscopicity of the panels, which was expected as the heat treatment of the particles reduced their hygroscopicity due to the reduction of heat absorption sites.

However, both "in natura" and heat-treated sugarcane bagasse particles were expected to be more hygroscopic than Pinus particles, as their holocellulose contents are higher (Table 2). This lower hygroscopic equilibrium humidity may have occurred because heat treatment as well as pressing at $180^{\circ} \mathrm{C}$ may have led to the migration of the extractives present inside the sugarcane bagasse particles to their outermost part.
Nevertheless, the hygroscopic equilibrium contents observed in this study are compatible with the literature (Teixeira et al., 2015).

It was also verified that the hygroscopic equilibrium humidity of the panels containing 50, 75 and $100 \%$ of treated particles was lower by $7.76 ; 12.49$ and $12.98 \%$ at the moisture of panels containing Pinus particles, which is possibly due to the decomposition of hemicelluloses, thus resulting in the reduction of adsorption sites for bonds with water molecules. Thickness swelling and linear expansion were lower in panels containing about $75 \%$ and $100 \%$ heat-treated sugarcane bagasse particles (Figures $1 \mathrm{~B}$ and $1 \mathrm{C})$. Probably these particles, when heat

Revista Árvore 2019;43(5):e430502 
treated, had their chemical composition modified. The main effects of heat treatment are the removal of part of hemicelluloses, leading to an increase in the degree of crystallinity of cellulose, in addition to a reduction in the degree of polymerization of both cellulose and lignin (Pelaez-Samaniego et al., 2013). These modifications result in increased particle density due to the higher proportion of lignin and crystalline cellulose per unit of volume. As a result, these particles become more hydrophobic and, when pressed in the presence of adhesive, form more stable panels thus exhibiting lower rates of linear expansion and thickness swelling.

It is observed that panels made of pine particles adsorbed less water vapor than panels from sugarcane bagasse particles (Figure 1D). This is because sugarcane bagasse has a higher percentage of holocellulose than Pinus (Table 2), indicating that there is a higher proportion of hemicelluloses and cellulose (crystalline and amorphous). Thus, the higher content of hemicelluloses and amorphous areas of cellulose causes an increase in sugarcane bagasse hygroscopicity. Another factor that may have affected water vapor adsorption is particle density. Oliveira et al. (2016) suggest that the high value of water adsorbed on sugarcane bagasse panels may be a consequence of the low material density compared to Pinus and Eucalyptus. Therefore, a larger quantity of particles per area would be required to form a predetermined density mats, resulting in increased availability of water vapor sorption and adsorption sites.

Furthermore, the effect of heat treatment was only significant when comparing the panels containing sugarcane bagasse particles in the proportion of $100 \%$ (Figure 1D). Panels made of treated particles adsorbed about $19.21 \%$ less water vapors than panels with untreated cane bagasse particles. Increasing particle density as a function of heat treatment may have reduced the quantity of particulate matter required to form the mats, thereby decreasing the availability of adsorption sites. In addition, the chemical modifications caused also contributed to the formation of more stable panels.

Panels made of $100 \%$ "in natura" sugarcane bagasse particles were lower than those established by ANSI A208.1 (1993), which is $4 \mathrm{kgf.cm}{ }^{-2}$ for perpendicular traction (Figure 2A). Oliveira et al. (2016) found similar results, $2.65 \mathrm{Kgf.cm}^{-2}$. These values below the norm may be related to the high percentage of parenchyma and fiber sheath lining the metaxylem vessels, which causes larger spaces within the panels and lower perpendicular tensile strengths (Belini et al., 2010).

The perpendicular tensile strength and screw pullout of Pinus particleboard panels was significantly higher than the strength of those made of sugarcane bagasse particles (Figures 2A and 2B). This is probably due to the higher basic density of the Pinus particles, thus requiring smaller amounts of particles to form the panel and consequently having a higher particle wettability, improving these properties.

The thermal-rectification of sugarcane bagasse particles significantly affected the panels, increasing their perpendicular tensile strength (Figure 2A). This increase can be attributed to the reaction of extractives with lignin, which can generate products with adhesive characteristics, thus increasing the adhesive bond and, consequently, the internal bonding of the panels, as reported by Chow and Pickles (1971).

The minimum value for the screw pullout test is 90 kgf. Therefore, all manufactured panels had values above the norm, proving to be suitable for use in the furniture industry for fastening screws (Ansi A208.1, 1993).

The $100 \%$ BG treatment had the lowest mean values for Janka hardness (Figure 2C). However, the effect of heat treatment of sugarcane bagasse particles was significant only in panels containing $75 \%$ and $100 \%$ of treated particles, which were similar to Pinus panels. This can be explained by the fact that the heat treatment favors the reduction of hydroxyl groups and increases the lignin contents, thus improving the dimensional stability of the panel and its mechanical properties (Bonigut et al., 2014).

The results for MOE and MOR were higher than the minimum values required by ANSI A208.1 (1993) (Figures $2 \mathrm{D}$ and $2 \mathrm{E}$ ). It is noteworthy that for the EOM, the panels are classified in class M-S, since all treatments presented average values higher than 19000 Kgf. $\mathrm{cm}^{-2}$. For MOR, the panels can be classified in category $\mathrm{M}^{-2}$ whose minimum value is $145 \mathrm{Kgf.cm}$. Therefore, it is possible to indicate them for industrial and commercial use.

Ashori et al. (2009) and Fiorelli et al. (2011) found similar results for MOE and MOR when analyzing medium and high density panels made of sugarcane 
bagasse using urea-formaldehyde and castor resin as an adhesive, respectively.

The properties of all panels were superior to those established in ANSI A208.1 (1993), showing, for this property, that these panels can be used in the manufacture of floors.

\section{CONCLUSION}

- The difference in basic particle density, even when added in different proportions, did not affect the final density of the panels.

- Overall, the physical properties of the panels containing $75 \%$ and $100 \%$ treated sugarcane bagasse particles were better than the physical properties of the Pinus particleboard panels, except for the water adsorption test.

- In general, heat treatment of sugarcane bagasse particles improved the physical properties of the panels containing 75 or $100 \%$ of these particles in their mix.

- The perpendicular tensile strength and screw pullout of the panels made of Pinus particles were higher than the resistance of the panels made of sugarcane bagasse particles.

- Heat treatment affected the mechanical properties differently. Panels containing $25 \%$ of heat treated particles for perpendicular traction and $75 \%$ for Janka hardness were higher than those produced with untreated particles. For the other mechanical tests, there was similarity between panels.

- The properties of the panels are within the limits established by ANSI A208.1 (1993), except for the perpendicular tensile test, in which the panels produced with untreated sugarcane bagasse particles obtained lower averages compared to the others.

\section{REFERENCES}

American National Standard - ANS. Mat-formed wood particleboard: specification ANS. ANSI/A 208.1.1993. Gaithersburg; 1993. 9 p.

American Society for Testing and Materials ASTM. D 1084-97: Standard test methods for viscosity of adhesives. West Conshohocken: ASTM Internacional; 1998.
American Society for Testing and Materials ASTM. D 2471-99: Standard test method for gel time and peak exothermic temperature of reacting thermosetting resins (Withdrawn 2008), ASTM International. West Conshohocken: ASTM Internacional; 1999. 3p. doi: 10.1520/D2471-99.

American Society for Testing and Materials - ASTM D-1037-93: Standard Test Methods for Evaluating Properties of Wood-Base Fiber and Particle Panel Materials. Annual book of ASTM Standards. Philadelphia; 2002.

American Society for Testing and Materials - ASTM. D 1490-01: Standard test method for nonvolatile content of urea-formaldehyde resin solutions. West Conshohocken: ASTM Internacional; 2013. 2 p.

American Society for Testing and Materials ASTM. E70-07: Standard test method for ph of aqueous solutions with the glass electrode. West Conshohocken: ASTM Internacional; 2015.

American Society for Testing and Materials. ASTM. Standard methods of evaluating properties of woodbase fiber and particles materials. Philladelphia; 1982

Araújo SO, Vital BR, Mendoza ZMSH, Vieira TA, Carneiro ACO. Propriedades de madeiras termorretificadas de Eucalyptus grandis e SP. Scientia Forestalis. 2012;40(95):327-36.

Ashori A, Nourbakhsh A, Karegarfard A. Properties of medium density fiberboard based on bagasse fibers. Journal of Composite Materials. 2009;43(18):1927-34.

Battistelle RAG, Fujino DM, Silva ALC, Bezerra BS, Valarelli ID. Physical and mechanical characterization of sugarcane bagasse particleboards for civil construction. Journal of Sustainable Development of Energy, Water and Environment Systems. 2016;4:40817. doi: dx.doi.org/10.13044/j.sdewes.2016.04.0031

Belini UL, Tomazello Filho M, Louzada JLPC, Rodrigues JC. Aspectos anatômicos e tecnológicos de painéis confeccionados com fibras de eucalipto e cana-de-açúcar. Cerne. 2010;16:48-52.

Benjamin Y, Görgens JF, Joshi SV. Comparison of chemical composition and calculated ethanol yields of sugarcane varieties harvested for two growing seasons. Industrial Crops and Products. 2014;58:13341. doi: doi.org/10.1016/j.indcrop.2014.04.010. 
Bonigut J, Krug D, Stuckenberg P. Dimensional stability and irreversible thickness swell of thermally treated oriented strandboards (OSB). European Journal of Wood and Wood Products. 2014;72(5):593-99.

Chow SZ, Pickles KJ. Thermal softening and degradation of wood and bark. Journal Wood and Fiber Science. 1972;3(3):166-78.

Companhia Nacional de Abastecimento CONAB. Acompanhamento da safra brasileira de cana-de-açúcar. Brasília: CONAB; 2017. v.4. Disponível em: "file://C:/Users/emila/Downloads/ BoletimZCanaZ3ZLevantamentoZ17-18.pdf.pdf”

Del Río JC, Marques G, Lino AG, Lima CF, Colodette JL, Gutiérrez A. Lipophilic phytochemicals from sugarcane bagasse and straw. Industrial Crops and Products. 2015;77:992-00. doi: 10.1016/j.indcrop.2015.09.064.

Fiorelli J, Lahar FAR, Nascimento MF, Savastano Junior H, Rossignolo JA. Painéis de partículas à base de bagaço de cana e resina de mamona - produção e propriedades. Acta Scientiarum Technology. 2011;33(4):401-06. doi: 10.4025/actascitechnol. v33i4.9615

Goldschimid O. Ultraviolet spectra. In: Sarkanen KV, Ludwig CH. Lignins: occurrence, formation structure and reactions. New York: J. Wiley; 1971. p. 241-266.

Gomide JL, Demuner BJ. Determinação do teor de lignina na madeira: método Klason modificado. $\mathrm{O}$ Papel.1986;47(8):36-38.

Magalhães MA, Carneiro ACO, Silva CMS, Vital BR, Martins MA, Cândido WL. Avaliação da torrefação da madeira em curtos tempos de residência em um reator tipo rosca sem fim. Revista Ciência da Madeira. 2018;9(3):160-69.

Maloney TM. Mordern particleboard and dry-process fiberboard manufacturing. San Francisco: Millir Freeman; 1993. ISBN-13: 978-0879305291.

Melo RR, Santini EJ, Haselein CR, Stangerlin DM. Propriedades físico-mecânicas de painéis aglomerados produzidos com diferentes proporções de madeira e casca de arroz. Ciência Florestal. 2009;19(4):449-60. doi: http://dx.doi. org/10.5902/19805098899.
Mendes FR, Mendes LM, Abranches RAS, Santos RC, Guimarães Júnior JB. Painéis aglomerados produzidos com bagaço de cana em associação com madeira de Eucalipto. Scientia Forestalis. 2010;38(36):285-95.

Oliveira SL, Mendes RF, Mendes LM, Freire TP. Particleboard panels made from sugarcane bagasse: characterization for use in the furniture industry. Materials Research. 2016;19(4):914-22. doi: dx.doi. org/10.1590/1980-5373-MR-2015-0211.

Pelaez-Samaniego MR, Yadama V, Lowell E, Espinoza-Herrera R. A review of wood termal pretreatments to improve wood composite properties. Wood Science and Technology. 2013;47:1285-1319. doi: doi.org/10.1007/s00226-013-0574-3.

Protásio TP, Mendes RF, Scatolino MV, Mendes LM, Trugilho PF, Melo ICNA. Estabilidade térmica de painéis aglomerados de bagaço de cana de açúcar e madeira de Pinus spp. Scientia Forestalis. 2015;43(107):683-91.

Rocha GJM, Nascimento VM, Gonçalves AR, Silva VFN, Martín C. Influence of mixed sugarcane bagasse samples evaluated by elemental and physical-chemical composition. Industrial Crops and Products. 2015;64:52-58. doi: https://doi. org/10.1016/j.indcrop.2014.11.003.

Santos TS, Carvalho GP, Guimarães Júnior JB, Protásio TP, Mendes RF. Tratamento térmico de lâminas de Pinus oocarpa para melhoria das propriedades físicas de painéis compensados. Enciclopédia Biosfera. 2014;10(19):1789-95.

Silva VLMM, Gomes WCO, Alsina LS. Utilização do bagaço de cana de açúcar como biomassa adsorvente na adsorção de poluentes orgânicos. Revista Eletrônica de Materiais e Processos. 2007;2:27-32.

Soares SS, Guimarães Júnior JB, Mendes LM, Mendes RF, Protásio TP, Lisboa FN. Valorização do bagaço de cana-de-açúcar na produção de painéis aglomerados de baixa densidade. Revista Ciência da Madeira. 2017;8(2):64-73. doi: http://dx.doi. org/10.15210/cmad.v8i2.10589.

Technical Association of Pulp and Paper Industry. TAPPI. Lignin in wood: T 222 om-98. Atlanta: 2000. 
Technical Association of Pulp and Paper Industry. TAPPI. Sampling and preparing wood for analysis, T257 om-52. Atlanta:1994.

Technical Association of Pulp and Paper Industry. TAPPI. Test methods T 204 om88: solvent extractives of wood and pulp. v.1. Atlanta: Tappi Technology Park, 1996.

Technical Association of Pulp and Paper Industry. TAPPI. Test methods T 264 om88: preparation of wood for chemical analysis. v.1. Atlanta: Tappi Technology Park, 1996.

Teixeira LP, Andrade ET, Espíndola JZ, Pereira RG. Determinação do equilíbrio higroscópico e do calor isostérico do bagaço de cana-de-açúcar.
Revista Engenharia Agrícola. 2015;35(3):55566. doi: dx.doi.org/10.1590/1809-4430-Eng.Agric. v35n3p555-566/2015.

Vital BR. Métodos de determinação da densidade da madeira. Viçosa, MG: SIF/UFV; 1984.

Vital BR, Andrade PIL, Carneiro ACO, Cabral CPT, Carvalho AMM. Estabilidade dimensional e resistência à tração perpendicular de painéis fabricados com partículas termorretificadas oriundas de embalagens de Pinus. Revista Árvore. 2014;38(5):951-59. doi: http:// dx.doi.org/10.1590/S0100-67622014000500020.

Vital BR, Trugilho PF. Variação dimensional e uso da Madeira de Eucaliptus. Informe Agropecuário. 1997;18(186):57-61. 